Monika Samsel-Chojnacka

Uniwersytet Gdański

\title{
Figura błazna jako alter ego Bergmana w teatrze
}

\author{
The jester figure as an alter-ego of Ingmar Bergman
}

One of Bergman's favourite figures was the jester or the clown. When appearing on stage, they gather the whole attention of both audience and other characters. In theatre productions Bergman used three strategies to express his fondness for this figure - he either emphasized jesters already existing in the text of the drama, provided other characters with clownish features (both visual and mental), or he even created clown-like figures and added them to the original drama. This was done not only to stress comic aspects, but mainly to expose the psychological complexity of the personalities of these figures. In my article, I analyse all three levels of this phenomenon in productions of Shakespeare, Ibsen and Gombrowicz, trying to find the source of inspiration behind them, as well as a common thread between them.

Key words: Ingmar Bergman, jester, clown, Swedish theatre, Shakespeare

Słowa klucze: Ingmar Bergman, błazen, klown, szwedzki teatr, Szekspir

Z okładki numeru pierwszego (z 1998 r.) czasopisma Dramat (Wanselius 1998: I), wydawanego przez Królewski Teatr Dramatyczny w Sztokholmie, całkowicie poświęconego twórczości Ingmara Bergmana w Dramaten, spogląda na nas sam reżyser, $\mathrm{w}$ cylindrze, $\mathrm{z}$ przyczepionym nosem klowna. To swoisty hołd dla postaci błazna oraz związku tego wielkiego twórcy z kuglarskim rodowodem teatru.

Jedną $\mathrm{z}$ jego ulubionych postaci, która zawsze magnetycznie przyciąga uwagę widzów, jest Błazen. Ilekroć pojawia się na scenie, skupia na sobie uwagę wszystkich obecnych. Bergman od dzieciństwa dużym sentymentem darzył sztukę cyrkową. Gdy był małym chłopcem, uwielbiał chodzić z bogatą ciotką na pokazy cyrku Schumanna. Wspomina o tym w autobiografii zatytułowanej Laterna Magica:

Wydarzenie to zawsze wprawiało mnie w gorączkowe podniecenie: (...) wchodzenie do ogromnego, rzęsiście oświetlonego drewnianego budynku, tajemnicze zapachy (...), grzmiąca orkiestra, magia przygotowań do występów, ryk drapieżników za czerwonymi draperiami korytarzy dla jeźdźców. Ktoś szepnął, że w ciemnej szczelinie pod kopułą pokazał się lew, klowni byli przerażający i zwariowani, zasypiałem z emocji i budzi- 
łem się przy cudownej muzyce: młoda kobieta w bieli jeździła na ogromnym czarnym ogierze. Owładnęła mną miłość do tej młodej kobiety. Włączyłem ją do moich igraszek fantazji i nazwałem Esmeraldą (może tak się nazywała) (Bergman 1991: 14).

Motyw cyrku pojawia się również nieco później, na wczesnym etapie twórczości Bergmana, w jednym z najsłynniejszych jego filmów z tego okresu, czyli Wieczorze kuglarzy (Bergman 1953). Cyrk przyjeżdża do małego miasteczka. By przedstawienie się odbyło, cyrkowcy muszą wypożyczyć kostiumy teatralne, jednak podczas wizyty w przybytku Melpomeny zostają wyśmiani przez aktorów uważających się za prawdziwych artystów. Dyrektor cyrku Albert (Åke Grönberg) przeżywa także szereg upokorzeń związanych ze zdradami kochanki oraz z niezbyt ciepłym przyjęciem przez dawno niewidzianą żonę. Wieczorne przedstawienie kończy się klapą i kolejnym poniżeniem Alberta przez aktorską gawiedź. Następnego dnia nieszczęśni cyrkowcy wyruszają dalej w drogę.

Tadeusz Szczepański w Zwierciadle Bergmana podkreślał chwytliwość metafory kina jako cyrku, czyli sztuki o jarmarcznym rodowodzie (Szczepański 1999: 148). Posiadający jarmarczne korzenie cyrk jest plebejskim bratem teatru, zwłaszcza tego kuglarskiego, bawiącego gawiedź na odpustach, o czym reżyser przypomina między innymi w Siódmej pieczęci (Bergman 1957), gdzie popisy wędrownej trupy aktorskiej noszą znamiona popularnej rozrywki dla niewyrobionej publiczności, a nie sztuki wysokiej, z jaką teatr kojarzy się współcześnie. Szczepański powołuje się również na artykuł Bergmana zatytułowany Jesteśmy cyrkiem!, który zazwyczaj interpretowany jest jako manifest twórcy filmowego, jednak równie dobrze może odnosić się do człowieka teatru: „Jesteśmy cyrkiem, dzikimi odgłosami i King Kongiem, jesteśmy na śmierć i życie prawdziwi lub fałszywi, piękni i niesamowici, jesteśmy katarynką i sonatą, czarodziejami, kuglarstwem, snami i diabelstwem. Mamy nieograniczoną władzę nad tymi, którzy nami pogardzają" (Bergman 1953: 31).

Postaci cyrkowców i kuglarzy służyły Bergmanowi do głębszej refleksji nad losem i kondycją artysty w społeczeństwie. Przeważnie pogardzani, odrzucani przez mieszczańskie społeczeństwo, zmuszeni do tanich sztuczek, by przypodobać się widowni. Jak pisze Szczepański:

W Wieczorze kuglarzy sztuka traci swój nimb nieomal sakralnego wtajemniczenia, jaki zachowała jeszcze w Do radości czy w Letnim śnie, i zostaje zdegradowana do rangi podejrzanej szarlatanerii. Niezależnie od miejsca zajmowanego w hierarchii kultury wszyscy artyści tworzą kastę ledwie tolerowanych pariasów, którzy wegetują na marginesie mieszczańskiego społeczeństwa, zakłócając jego syty spokój (Ibid.: 152).

Maria Bergom-Larsson w eseju Od klowna do pasożyta. Artysta i społeczeństwo twierdzi, że już zarówno w twórczości filmowej, jak i w refleksji teoretycznej w latach 50. Bergman przeżywał konflikt między prawdą wewnętrzną artysty a chęcią 
przypodobania się szerszej publiczności. To, co dla twórcy jest drogą przez mękę, stanowi dobrą zabawę dla publiczności. Widzimy to choćby na przykładzie jednego z bohaterów Wieczoru kuglarzy, klowna Frosta. Bergom-Larsson pisze:

Cyrk i teatr to barokowe symbole życia. Dla paru sztuczek stoimy tam na scenie i odgrywamy swoje role. Potem wszystko się kończy. Klown i aktor to symbole Człowieka. "Życie jest snem”, który szybko przemija. Wieczór kuglarzy budzi skojarzenia z ogólnym obrazem świata (Bergom-Larsson 1993: 78).

W Wieczorze kuglarzy reżyser zrównuje sztukę teatralną ze sztuką cyrkową, demaskując fałsz tej pierwszej. Teatr nie jest tu niczym lepszym od swego plebejskiego kuzyna. Obydwaj posługują się iluzją i grają z widzem, żebrząc o jego uwagę.

Innego szarlatana Bergman uczynił bohaterem swego filmu pt. Twarz (Bergman 1958a). Albert Emanuel Vogler jest właścicielem wędrownego Magnetycznego Teatru Leczniczego. Już sama nazwa jego biznesu brzmi bardzo podejrzanie. Jest on jednocześnie magikiem, hipnotyzerem oraz właścicielem zagadkowego aparatu zwanego laterna magica. Jego trupa to zbieranina kuriozów, istna ludzka menażeria. Androgyniczna żona, która podróżuje w męskim przebraniu, dwustuletnia babka zajmująca się tworzeniem eliksirów i wyglądająca niczym średniowieczne wiedźmy palone na stosach. W tym obrazie Bergman również zastanawia się nad rolą artysty w społeczeństwie. Szczepański pisze: „Owa nieustanna migotliwa oscylacja prawdy i fałszu, szczerości i kłamstwa, sedna i pozoru, realności i złudzenia, twarzy i maski czy wreszcie - jak w zwodniczym mechanizmie percepcji filmowej - światła i ciemności stanowi główną zasadę dramaturgiczną filmu" (Szczepański 1999: 217).

W filmie Rytuał (Bergman 1967) bohaterem zbiorowym jest kabaretowe trio prześladowane ze względu na rzekome szerzenie pornografii w swoich występach. Film dotyka problemów cenzury, moralności oraz granic wolności wypowiedzi. Cyrkowcy i aktorzy kabaretowi pojawiają się również w obrazie o wiele późniejszym, bo nakręconym pod koniec lat 70. w Niemczech, w mrocznym Jaju węża (Bergman 1976). Jako grupa biednych, lecz wolnych artystów stanowią oni przeciwwagę dla niemieckiego mieszczaństwa, w którym w latach 20. ubiegłego wieku kiełkuje już totalitaryzm.

Kwestia misji artysty w społeczeństwie oraz zakres wolności twórcy, a jednocześnie również refleksja nad pasożytniczym charakterem sztuki bardzo często absorbowały Bergmana. Motyw teatru, zarówno jako rzeczywistego miejsca pracy, jak i metafory życia, pojawiał się wyjątkowo często w jego filmach, przedstawieniach i w prozie.

Spośród kuglarzy największe zainteresowanie Bergmana zawsze budził klown, błazen. W inscenizacjach teatralnych, które wyszły spod jego ręki, ta sympatia do postaci klowna jest widoczna na kilku poziomach. Pierwszy to przede wszystkim 
wyeksponowanie postaci błaznów w inscenizowanych tekstach dramatycznych. Drugi to nadanie cech błazeńskich (zarówno wizualnych, ale też i charakterologicznych) postaciom, które według oryginalnego tekstu dramatycznego nie noszą takowych znamion. Trzeci to dopisanie dodatkowych bohaterów - błaznów lub klownów. Tworząc klownów - zarówno tych nowych, jak i tych przerobionych z już istniejących postaci - Bergman nie sygnalizował jednak wyłącznie cech komicznych, wręcz przeciwnie - podkreślał złożoność psychologiczną tych bohaterów.

Jednym z takich bohaterów jest doktor Rank z Domu lalki Ibsena, grany przez Erlanda Josephsona (Bergman 1989). Majętny przyjaciel rodziny Helmerów, sekretnie zakochany w pani domu, będący jej powiernikiem i wsparciem, jest jednocześnie śmiertelnie schorowanym samotnym mężczyzną, któremu zostały ostatnie chwile życia. W scenie powrotu Nory (Pernilla August) z Thorvaldem (Per Mattsson) z balu Rank, który również był na nim obecny, przychodzi się z nimi pożegnać. Wie, że już zapewne nigdy się nie zobaczą. Siedzą we trójkę w mieszczańskim salonie, przy stole nakrytym szydełkową serwetą. Dwie osoby, które już wiedzą, że mają każda na swój sposób złamane życie - Rank i Nora, oraz Thorvald Helmer, który jeszcze nie jest świadomy czekającej go ruiny. Erland Josephson wygląda nobliwie w czarnym fraku, płaszczu oraz cylindrze. Jeden element stroju nie pasuje do całości - to czerwony nos klowna, który aktor ma przez całą scenę na twarzy. Wprawdzie wytłumaczeniem mógłby być fakt powrotu z balu kostiumowego, ale obecność tego niewielkiego detalu przez cały czas trwania rozmowy jest aż zbyt znacząca w przestrzeni teatralnej, pokazuje tragikomiczny wymiar postaci Ranka, który - jak sam wcześniej mówił - jest najbardziej chorym ze swoich pacjentów. Ukochana Ranka zaraz odejdzie od męża, dla którego zdrowia postawiła wszystko na jedną kartę, fałszując przed laty weksel, by zdobyć pieniądze na jego leczenie. Ale nie odejdzie przecież do Ranka, gdyż on sam wkrótce umrze. Thorvald, przyjaciel Ranka, który ma u swego boku tak oddaną żonę, nie doceni jej w godzinie prawdy. Rank zdaje sobie sprawę z tego niczym szekspirowskie błazny obdarzone darem prorokowania i wglądem w tajniki ludzkiej duszy.

Identyczny nos ma na plakacie reklamującym bergmanowską adaptację sztuki Witolda Gombrowicza Iwona, księżniczka burgunda (Bergman 1996) Nadja Weiss, odtwórczyni roli tytułowej. W samym spektaklu ten rekwizyt ani razu się nie pojawia, jednak farsowość postaci została podkreślona kostiumami rodem $\mathrm{z}$ wodewilu. Elementem łączącym Iwonę $\mathrm{z}$ tradycyjnym wizerunkiem klowna jest również szopa kręconych niesfornych rudych loków. Bohaterka grana przez Weiss jest postacią tragiczną, budzącą na dworze pogardę i szyderstwo, ale jednocześnie również lęk. Bergman usunął większość replik Iwony, czyniąc z niej niemą, groźną dla porządku królestwa postać. Staje się ona milczącym tricksterem, której zachowanie podaje w wątpliwość zasady istnienia dworu. 
W Peer Gyncie (Bergman 1991a) reżyser nadał cechy błazeńskie tytułowemu bohaterowi. Börje Ahlstedt w czarnym meloniku, przydużych butach i luźnym garniturze bawi publiczność. Jego fantazja i rozmach, z jakim gestykuluje i porusza się, przywodzą na myśl klownowskie cyrkowe popisy albo slapstickowe komedie z Chaplinem i Flipem i Flapem. Kostiumem przypomina też Estragona i Vladimira z beckettowskiego Czekajac na Godota, co nadaje Peerowi uniwersalny wymiar everymana $w$ absurdalnym świecie.

Jego popisy retoryki, snute fantazje są podszyte błazeńską fanfaronadą. Jednak Peer Ahlstedta nie jest jedynie zabawny, jak ma to miejsce w scenie, gdy w samych kalesonach zostaje porzucony przez Anitre (Solveig Ternström). Jest przede wszystkim przez cały czas sobą, realizując maksymę trolli: „trollu, poprzestań na sobie!” (Ibsen 1967: 77). Pozostaje więc małym człowieczkiem śniącym o wielkości, żałosnym w swych rojeniach, bezustannie goniącym za bogactwem i ułudą szczęścia egocentrykiem. Im większe te mrzonki, tym bardziej tragikomiczny wymiar postaci Peera, który pragnie zyskać sławę i zdobyć cały świat, a jednocześnie traci sam siebie. Bergman ukrył jeszcze jedno błazeńskie odwołanie w spektaklu - ale tym razem budzące grozę. To spotkany w czasie burzy na statku Nieznajomy Pasażer (Björn Granath), który jest złowróżbnym wysłannikiem z zaświatów. Jego twarz jest kredowo blada - jak u klowna, a całą postać obleka czarna opończa. Przypomina tym samym zarówno postać Śmierci z Siódmej pieczęci, jak i charakteryzacją Sganerela z inscenizacji Don Juana (Bergman 1965) w teatrze w Malmö (w tej roli Toivo Pawlo) i Mefistofelesa z Prafausta (Bergman 1958b), również granego przez Toivo Pawlo, w tym samym teatrze.

Uwypuklenie postaci trefnisiów ma miejsce również w inscenizacji tekstów szekspirowskich, aczkolwiek Bergman stosuje tu głównie dwa ostatnie spośród wskazanych powyżej zabiegów, a więc nadawanie innym postaciom znamion i rysów błazeńskich oraz dopisywanie własnych postaci. W samych tylko tekstach szekspirowskich reżyserowanych przez niego znajdujemy następujących błaznów: Wieczór Trzech Króli - Feste i Fabian, Król Lear - Błazen, Hamlet - Yorick (choć nie do końca obecny ciałem i duchem), Zimowa opowieść - Klaun, syn Pasterza oraz niejednoznaczny Autolikus. Jak widać, jest to całkiem liczna galeria postaci, bardzo różniących się od siebie zarówno aparycją, usposobieniem, funkcją w dramacie, jak i potencją czynienia rzeczy paranormalnych czy też skłonnością do opowiadania się po stronie dobra lub zła.

Antropolog Monika Sznajderman w pracy o figurze błazna w kulturze już od samego początku akcentuje, że aktorzy, kuglarze, a więc i błazny należeli do kasty wykluczonej w średniowiecznym społeczeństwie. Interpretuje ona ten fakt w sposób następujący:

O czym świadczy fakt tak kategorycznej i długotrwałej ekskluzji? Wyraźnie o tym, że błazeńską profesję, mocniej niż wszystkie inne, postrzegano jako profesję sakralną, 
fascynującą, ale i budzącą lęk. (...) Jacques Le Goff tłumaczy ów paradoksalny fakt [waloryzację pozytywną - przyp. M.S.-Ch.] chęcią rehabilitacji kuglarza zgodnie ze zmieniającym się światopoglądem chrześcijańskim, ale czy nie trzeba by tu jednak raczej dostrzec potwierdzenia tej dawno przez religioznawców odkrytej prawdy, że każde zjawisko należące do porządku sakralnego z natury swojej jest zjawiskiem ambiwalentnym: zarówno niebezpiecznym, jak i dobroczynnym, zarówno skalanym, jak i poświęconym, zarówno diabelskim, jak i boskim? (Sznajderman 2000: 16)

Badaczka sięga również na poziom pierwotnych znaczeń, próbując doszukać się w nich źródeł wyjątkowości postaci klowna.

Błazen był zatem przy dziele stworzenia i całkowicie się z tamtych czasów - czasów pierwotnego chaosu - wywodzi. Można powiedzieć, że jest istotą nieustannie wyciosywaną od nowa z surowego nieobrobionego pnia natury. Widać to choćby w etymologii słowa clown, które pierwotnie, jak podaje słownik etymologiczny języka angielskiego Erica Patridge’a, oznaczało chłopa, rolnika, śmiesznego mieszkańca miasta, gbura i prostaka, a które w różnych pokrewnych językach wywodzi się z pojęć określających takie idee, jak grudka ziemi, kloc, bryła, pień i pniak (Ibid.: 17).

I jeszcze jeden cytat:

Błazen, cyrkowy clown, bywa zatem zarówno twórcą, jak i ofiarą chaosu - swej własnej kreacji. Jego kontakty $\mathrm{z}$ chaosem, przyjmujące często formę zabawy (nawet gdy pada on ofiarą tego chaosu), odbierają jednak temu wrogiemu żywiołowi jego zwykły złowieszczy ciężar i stają się grą niewykorzystanymi możliwościami - pomimo groźby, że przyjmą one formę niespodziewanie wrogą, że chaos może przerwać tamę (Ibid.: 18).

Błazen jest zatem postacią niejednoznaczną, ma możliwość kontaktowania się z chaosem, a więc także z siłami ciemności. Jednocześnie zaś należy do porządku sakralnego. Jest więc niejako zawieszony pomiędzy nimi. Czy takich Błaznów pokazuje również Bergman?

Pierwszy to Feste, grany w inscenizacji Wieczoru Trzech Króli (Bergman 1975) z 1975 roku przez Ingvara Kjellsona. Nosi brązową koszulę i kubrak w podobnym odcieniu. Spodnie są obcisłe i zielonkawe, kończą się tuż pod kolanem na linii cholewki buta. Czasami okrywa się czerwonym płaszczem (podobnie jak Błazen w Królu Learze). Rekwizytem stale towarzyszącym Feste jest mały bębenek, na którym często sobie akompaniuje, wybijając rytm przyśpiewek. Jest to postać najbardziej ze wszystkich bohaterów Wieczoru Trzech Króli złożona, znajdująca się zarówno pomiędzy klasami społecznymi (pochodzi z ludu, jednak równie dobrze radzi sobie na dworze), jak i między pokoleniami (pamięta jeszcze ojca Oliwii, u którego służył, ale najprawdopodobniej jest odrobinę młodszy od Tobiasza). Ma sentymentalną duszę poety, bacznie obserwuje wydarzenia. 
W publikacji zatytułowanej Szekspir: leksykon możemy przeczytać między innymi: „Feste pełni ważną rolę komentatora, demaskującego głupotę i pozy bohaterów sztuki (np. długotrwałą żałobę hrabianki Oliwii). Jak na błazna przystało, często sięga po piosenkę, a jest ich w sztuce dziesięć, w tym piosenka finałowa" (Fabiszak, Gibińska i Kapera 2003: 187). Ale Feste nie jest wcale zwykłym trefnisiem, jak mogłoby to wynikać ze słownikowego opisu. Jest przede wszystkim najbardziej melancholijnym ze wszystkich błaznów. Jego liryzm i smutek Bergman uwydatnił w finale poprzez efekt padającego deszczu, który Feste właściwie wyczarowuje, by akompaniował jego piosence. Gdy Feste pojawia się pierwszy raz na scenie, widać od razu, że nie jest w najlepszej formie. Leży na deskach i ma problem z podniesieniem się, charczy, pociąga nosem. Maria (Solveig Ternström), służąca ich wspólnej pani, próbuje go zmotywować w mało elegancki sposób, wymierzając mu kilka sążnistych kopniaków, co raczej świadczy o braku współczucia i zrozumienie jego stanu. Może zabalował zeszłej nocy z Andrzejem (Sven Lindberg) i Tobiaszem (Ulf Johanson) i cierpi na „syndrom dnia następnego"? Jednak powodem jego kiepskiego samopoczucia i złego stanu zdrowia jest zapewne po prostu starość. Jak widzimy, Feste nie jest już młody, najprawdopodobniej był rówieśnikiem nieżyjącego już ojca Oliwii (Lil Terselius) lub był nawet trochę od niego starszy. Widać czasem, jak rozmasowuje sobie stawy, jakby cierpiał na reumatyzm. Jego głowę w miejscach, gdzie nie błyszczy łysina, pokrywają siwe kępki włosów. Do swej pani odnosi się trochę jak ojciec do kapryśnego dziecka, nie zapominając wszak, że jest jej podwładnym. Ona odpłaca się mu troską i tkliwością, wykonując drobne gesty w chwilach samotności, takie jak głaskanie go po głowie lub czułe zwracanie się do niego. Widać, że docenia nie tylko jego wysublimowany humor, ale i mądrość i dobroć. Feste nie jest zatem złym błaznem, z gatunku tych, których opisuje Sznajderman. Nie ma w sobie diaboliczności. Jest wesołym kompanem dla całej rozhasanej gromadki przebywającej na dworze Oliwii. Z początku uczestniczy wprawdzie w zawiązaniu intrygi mającej na celu upokorzenie bufonowatego Malvolia (Jan-Olof Strandberg), jednak wycofuje się, gdy pojmuje, że granica niewinnych żartów została przekroczona. W drugiej części spektaklu widzimy go bardzo rzadko w centrum wydarzeń, przy głównej osi sceny. Jest jednak stale na niej obecny - stoi z boku przy kulisach, skąd obserwuje akcję (tak jak wszyscy inni aktorzy). Nawet gdy za namową Andrzeja i Tobiasza odgrywa rolę egzorcysty w więzieniu, odwiedzając Malvolia, czyni to bez złośliwości. Gdy majordomus pada przestraszony na ziemię, ujawnia swą tożsamość, śpiewając jedną ze starych piosenek, na co Malvolio woła pełnym ulgi głosem: „Błazenku!”.

Jego przeciwieństwem był mały i sprytny Fabian (Urban Sahlin), jeden ze sług na dworze Oliwii. Pojawia się dopiero w scenie, gdy cała grupa siedzi w ukryciu, podpatrując czytającego list Malvolia. Fabian jest odziany w zielone pończochy 
i zielony kubrak, kaftan z małą białą kryzką oraz wysokie do kostki sznurowane buty z czubami.

Charakterystyczny jest jego makijaż - na biało umalowana twarz, wyskubane cienkie brwi, czarna obwódka dookoła oczu, lekko rozmazana na dole. Charakteryzacją przypomina dobrze znany z ikonografii wizerunek Pierrota. Jednak nie ma w nim krzty dobroduszności i melancholii tej postaci rodem z commedii dell'arte. Swoją złośliwością, grymasami, figlami przypomina raczej złowrogiego Arlekina. Bergman jak prawdziwy władca marionetek zlepił te dwie postacie w jedno. To Fabian droczy się z Cesariem, to on jest jednym z prześladowców Malvolia w więzieniu. Kostium Feste kojarzyć się też może ze strojem rzymskiego Merkurego, co właśnie sugerowałoby późniejsze powiązania z postacią Arlekina. Jednak te skojarzenia są moim zdaniem nietrafne, gdyż to Fabian, a nie Feste wywodzi się od tego złośliwego bohatera. Fabian jest również jednym z „pretendujących” do miana trickstera w tej grze. „Postać (...), która nie wie, co to dobro i zło, choć i za jedno, i za drugie jest odpowiedzialna, która zatem $\mathrm{z}$ racji swego archaicznego rodowodu wyprzedza wszelką etykę” - pisze Sznajderman. Po czym dodaje: „Trickster bywa negatywnym, demonicznym bohaterem, ale też zbawcą ludzkości, a nawet świętym" (Sznajderman 2000: 26).

Według Carla Gustava Junga trickster, mając zarówno naturę człowieka, jak i zwierzęcia, przewyższa ludzi swoimi nadludzkimi właściwościami, ale jest też głupszy od nich, ponieważ nie ma rozumu. Ani Feste, ani Fabian nie posiadają nadludzkich możliwości. Jednak coś z natury trickstera drzemie w każdym $\mathrm{z}$ nich.

Już pierwsza scena pojawienia się Feste daje dużo do myślenia. Gdy biedny błazen kuli się z bólu i zimna, Maria podchodzi i wymierza mu parę kopniaków. W kolejnej scenie daje mu kuksańca. Zastanawiające, przecież znają się od lat i lubią. Jednak jeśli przyjrzymy się bliżej poczynaniom Marii, małej czarownicy, która uwielbia wszystkim dyrygować i snuć intrygę za intrygą, dochodzimy do wniosku, że to ona pragnie pociągać za sznurki na dworze. Jest świadoma, że największą dla niej konkurencją jest właśnie starszy błazen. Wie, że ten swą umiejętnością tworzenia poezji ma władzę nad nastrojem swoich słuchaczy. To on jest zdolny przywołać deszcz (choć przekonamy się o tym dopiero w ostatniej scenie), on jest cichym obserwatorem wszystkich poczynań na dworze. Dlatego być może nieświadomie Maria widzi w nim konkurencję. Fabian jest prawdopodobnie w jej oczach zbyt młody i naiwny, by z nią rywalizować.

Błazen staje się tutaj postacią centralną, a sztuczki błazeńskie są sensem całej gry. Można to powiązać z tradycją karnawałową - święto Trzech Króli było świętem błaznów. Mirosław Słowiński tak pisze:

Prawie wszystkie igry święta błaznów stanowiły groteskową degradację różnych obrzędów i symboli religijnych. Szaleństwo rozpoczynało się w Boże Narodzenie, najczęściej 
w dzień św. Szczepana (26 grudnia) lub dzień Świętych Młodzianków (28 grudnia). W katedrach, kościołach po odśpiewaniu uroczystego Magnificat władanie świątynią hierarchia zmuszona była przekazywać młodym klerykom, którzy rozpoczynali swe rządy od wymazania twarzy sadzą, przywdziania błazeńskich kapturów, potwornych masek czy innych równie teatralnych strojów. W niebywałym harmidrze dokonywano wyboru (zazwyczaj z grona żebraków) błazeńskiego papieża, biskupa czy opata - nadając mu tym samym przywilej sprawowania rządów przynajmniej do święta Trzech Króli (Słowiński 1993: 34).

Mamy tu święto błaznów, przez błaznów i dla błaznów odgrywane. Pogodne, radosne, podszyte tylko odrobiną melancholii.

Inny Błazen (Jan-Olof Strandberg) jest bohaterem kolejnego szekspirowskiego spektaklu. W Królu Learze z 1991 roku (Bergman 1991b) to on zapowiada katastrofę. Przypomina Feste jedynie elementami swego stroju (projektowanego przez tą samą scenograf - Gunille Palmstiernę-Weiss). Podobnie jak on ubrany jest na zielono, jego kaftan jest zszyty z kilku materiałów różniących się od siebie odcieniami brązu, co miało odzwierciedlać złożoność jego osobowości. Jedyny bardziej rzucający się w oczy element to czerwona łata na tyle spodni. Na głowie ma zielono-beżową czapkę przypominającą swym kształtem raczej cyklistówkę niż typowo błazeńskie nakrycie głowy. Już podczas przedgry, prologu do sztuki dopisanego przez Bergmana, jest wywoływany przez tłum kuglarzy i wieśniaków, by przyłączył się do ich kompanii. Wtedy razem z nimi śpiewa piosenkę, która okazuje się prorocza. Gdy Lear zdejmuje koronę i kładzie ją na proscenium, nastaje okres swoistego bezkrólewia. O podobnym momencie, choć nie tak symbolicznym, a raczej bardziej dosłownym, pisze Sznajderman:

Z chwilą upadku monarchii każdy może się stać prawodawcą, bo w odpowiedzi na akt zniszczenia, czyli królobójstwa, otwiera się ogromna, pusta, całkowicie jednorodna przestrzeń, powstaje amorficzny świat chaosu, pozbawiony jakichkolwiek reguł, norm i sankcji; otwiera się więc miejsce dla dokonania nowej demiurgii. Ale ta błazeńska demiurgia nieustannie pozostanie jedynie chimerą, bowiem wolność „ogarnięta szałem anarchii” nie może przybrać żadnej stałej formy, jakiej w tym demiurgicznym akcie pragnęła (Sznajderman: 2000: 112).

$\mathrm{W}$ inscenizacji Bergmana to bezimienny Błazen staje się swoistym demiurgiem świata na opak wywróconego. To element karnawałowy, „święta głupców” były wszak nazywane „świętami odwrócenia” (Dudzik 2005: 54). To, co w czasie tych obchodów było „chwilowym zawieszeniem obowiązujących na co dzień praw”, tu staje się permanentne, a scena finałowa, w której scenografia rozpada się jak domek z kart, by zdemaskować machiny teatralne tkwiące za kulisami, zamiast przywracać pierwotny porządek świata, wróży rychłą apokalipsę. Ukłonem Bergmana w stronę quasi-apokaliptycznych wizji jest odwołanie do Nostradamusa zamiast do Merlina 
(jak było to w szekspirowskim tekście) w scenie 2. aktu III, kiedy to Błazen, wchodząc $w$ trans wieszczenia, odśpiewuje swoją proroczą piosenkę.

W Błaźnie nie ma nic z melancholii i liryzmu Feste, jest jednak w jego wypowiedziach spora doza filozoficznej refleksji. Taką rolę błazna opisuje między innymi Słowiński:

Błazen dostarcza więc spektaklu, któremu na imię obłęd, i otrzymuje za to we wnętrzu dworskiego świata przywilej mówienia prawdy, prawo do wolności słowa. Jego rola jest niepowtarzalna. Nie jest ani doradcą, ani sługą, ani dworzaninem, ani wyłącznie kuglarzem. Zarówno w historycznej rzeczywistości, jak i w wymiarze symbolicznym stanowisko błazna czyni go uprzywilejowanym „partnerem” monarchy. Relacja między nim a królem polega na swoistym porozumieniu lub, inaczej jeszcze, świadomości miejsca, w jakim ich odwieczny spektakl się odgrywa - dworu. Prawdę zaś tutaj tylko wtedy się toleruje, kiedy jest zamaskowana błazeństwem. Szaleństwo rozrywa wszelką normę, przenika wszystkie struktury - tak wnętrza człowieka, jak i społeczności, w której on żyje. Błazeństwo jest normowane (Słowiński 1993: 72).

Trefniś jest jedyną osobą, która śmie powiedzieć królowi prawdę prosto w oczy, nikt inny tego nie robi. To dzięki rozmowom z nim Lear dochodzi do anagnorisis. To „ironizujący filozof”, „mentor”, jak określa go Sznajderman w swojej refleksji nad dramatem Szekspira. Gdy siedzą obok siebie na granicy proscenium i rozmawiają o perspektywach przyjęcia Leara przez młodszą córkę (akt I, scena 5.), Błazen powoli gryzie jabłko, aż dochodzi do samego ogryzka. Jest to podyktowane metaforą zawartą w tekście - Regana i Goneryla są porównywane do kwaśnych jabłek z jednej jabłonki. Dotarcie do ogryzka (po angielsku core) może oznaczać także dotarcie do sedna, do meritum. Błazen odkrywa w tym momencie clou problemu Leara, mówi jedną z najbardziej kluczowych kwestii:

Błazen: Gdybyś był moim błaznem, wujaszku, kazałbym cię obić za to, żeś się przed czasem zestarzał.

Lear: Jak to?

Błazen: Nie wypada się zestarzeć, zanim się nie zmądrzeje (Shakespeare 1991: 52).

Mamy więc dwóch błaznów zbliżonych do siebie nie tylko wiekiem (Bergman zadbał o to, by obaj aktorzy byli rówieśnikami), ale już w III akcie również i statusem społecznym. Niestety, błazen znika ze sceny i już na nią nie wróci, gdy Lear sam stanie się błaznem i pośmiewiskiem gawiedzi. Słowiński podsumowuje taką sytuację, widząc w niej uniwersalną zasadę rządzącą pojawianiem się i znikaniem postaci błazna:

Ma on swoje miejsce w tym świecie tak długo, jak król pozostaje królem. Jest bowiem antytezą, niezbędną przeciwwagą umożliwiającą zachowanie równowagi sił. Kiedy 
Król przechodzi na pozycję błazna, rola błazna się kończy. Łamie się więc biegunowy porządek świata, łamie się dotychczasowy kształt szekspirowskiej tragedii (Słowiński 1993: 240).

Jeśli dodamy do tego grona Głupiego Tomka, to trafne staje się stwierdzenie, że wszyscy są w tym świecie błaznami. Jednakże w zestawieniu z Wieczorem Trzech Króli nie jest to wizja optymistyczna. Chaos przepowiedziany przez Błazna w akcie III należy do domeny trickstera. Nadaje to naszemu bohaterowi cech demonicznych, mimo że na pierwszy rzut oka mógłby się wydawać zwykłym domorosłym filozofem, szaławiłą, sowizdrzałem. Jego błazeństwo jest groźne, sprawia, że królestwo Albionu okrywa się całunem śmierci.

Kolejny błazen, który będzie mieć kontakty z zaświatami lub (mówiąc dokładniej) z ich przedprożem, to Grabarz z Hamleta (Ulf Johanson) (Bergman 1986). Zgodnie z tekstem szekspirowskim, gdzie w spisie osób mamy Clowns - two gravediggers, Bergman postanowił uczynić z Grabarza klowna. Dokonał jednak pewnej roszady osobowej. Mamy mianowicie jednego grabarza zamiast dwóch, ale towarzyszy mu dwóch muzykantów. Pojawiają się na scenie w sposób dość hałaśliwy, są wyciągani z piskiem lin z zapadni na małej platformie. Zanim ich zobaczymy, usłyszymy najpierw jazgotliwą muzykę graną na saksofonie, puzonie i bębnie. Muzykanci ubrani są bardzo fantazyjnie na biało, jeden z nich ma kryzę i błazeńską czapkę, drugi wielki kapelusz i pelerynę. Pomiędzy nimi siedzi Grabarz, który wygląda raczej jak typowy murarz: ma na sobie powalany wapnem kombinezon roboczy, wielkie buciory, flanelową koszulę, powycieraną marynarkę z jakimś podejrzanie wyglądającym orderem przypiętym na piersi, melonik i czerwony nos klowna. W dłoni dzierży brudną łopatę. W jego stroju - podobnie jak w wizerunku wspomnianego wcześniej bohatera Peer Gynta - można zauważyć nawiązania do wizerunku Charliego Chaplina. Grabarz-klown bardzo głośno śpiewa:

\footnotetext{
En hacka och en spade blott ett lakan såsom skrud, en grop i leran gästen fått vid maskars gästebud.

Den store Caesar dog förvisst Och sänktes ned i mull Och täpper där igen till sist Ett hål för dragets skull.

I unga dar när jag var kär Var allt så lustigt så. Jag smet från plikter och besvär, och livet låg framför mig då.
} 
Men ålderdomen smog sig på

Och tog mig utan prut

Och bar mig till et annat land,

Och där tog det roliga slut ${ }^{1}$.

Humor mu dopisuje, wyjmuje zza pazuchy piersiówkę, odkręca ją i dolewa alkohol do termosu, komponując w ten sposób kawę „z prądem”. Następnie wyciąga zapakowane w papier śniadaniowy kanapki i zaczyna je pałaszować. Traktuje śmierć jak zwykłą kolej rzeczy i nie widzi powodu, by zawód, który wykonuje, miał go w jakikolwiek sposób pozbawiać radości życia. Gdy rozmawia z Hamletem (Peter Stormare), żartuje, bawi się w gry słowne. Gdy pokazuje księciu czaszkę Yoricka, nie dziwi się, gdy Hamlet też zaczyna się nią bawić. Jest rubaszny, pogodny i beztroski.

Zastanawiać może jednak inny aspekt tej postaci. Grabarza gra ten sam aktor, który wcześniej grał Poloniusza. Z jednej strony nawiązuje to do tradycji teatru elżbietańskiego, gdzie aktorzy grali kilka ról w jednym przedstawieniu. $Z$ drugiej zaś odkrywa przed widzem błazeńską naturę Poloniusza - jego służalczość i bufonada są żałośnie śmieszne, a jego miny mogą bawić publiczność.

Sam Hamlet również jest obdarzony w tej inscenizacji cechami błazeńskimi. Uwielbia naśmiewać się z Rosenkrantza i Guildensterna, okrutnie przedrzeźnia często Poloniusza, kpi z poczynań Klaudiusza. Błazenady i wygłupy księcia denerwują jego matkę i ojczyma. Jednak w interpretacji bergmanowskiej w Elsynorze prawie wszyscy w mniejszym lub większym stopniu są błaznami, śmiesznymi, żałosnymi i bardzo ludzkimi w swoich niedoskonałościach.

Wesołego i pogodnego błazna spotykamy w końcu w Zimowej opowieści (Bergman 1994). To syn pasterza, zwany Klownem. W polskich przekładach bywa nazywany Wesołkiem (Maciej Słomczyński), Pajacem (Leon Ulrich) lub też po prostu Synem Pasterza (Stanisław Barańczak). Na potrzeby niniejszego tekstu pozostanę jednak przy Klownie, ponieważ tak jest ta postać nazywana w scenariuszu opartym na tłumaczeniu autorstwa Britt G. Hallqvist i Claesa Schaara. W inscenizacji Bergmana Klown nie nosi wprawdzie czerwonego nosa ani cyrkowego stroju, lecz nawet bez tych atrybutów potrafi rozbawić publiczność. Pojawia się tuż przed końcem pierwszej części przedstawienia, gdy jego ojciec znajduje porzuconą Perditę (Kristina Törnqvist). Wbiega, a właściwie wjeżdża na scenę na łyżworolkach,

\footnotetext{
${ }^{1}$ Pieśń dopisana do dramatu przez Bergmana w moim tłumaczeniu, na podstawie egzemplarza suflerskiego z Archiwum Dramaten: „Kilof i sama łopata / prześcieradło za strój, / dół w glinie gość otrzymał / na uczcie robaków. // Wielki Cezar umarł / I zakopany w glebie / I w końcu na wypadek przeciągu / Zatyka tam dziurę. // W młodości, gdy byłem zakochany / Wszystko uciesznym się zdawało. / Wymigiwałem się od obowiązków / A życie całe było przede mną. // Lecz starość skradła się / I zawładnęła mną kornie / I do innej krainy mnie przeniosła / A wtedy nastąpił wesoły koniec" (Archiwum Dramaten 1986: 132).
} 
z pilotką na głowie, w ręku dzierżąc kij hokejowy. Zziajany donosi ojcu, że widział rozbijający się statek i że niedźwiedź ze smakiem spałaszował Antygonusa (Ingvar Kjellson), nie przejmując się, kto zacz. Opowiadając, nadmiernie gestykuluje, używa wyrazów dźwiękonaśladowczych, bawiąc się przy tym niezmiernie, mimo całej grozy sytuacji. Gdy ojciec wyciąga do niego swoją piersiówką, by go poczęstować, chłopak pociąga nosem i odmawia, mówiąc, że ma przecież dopiero osiem lat (salwy śmiechu na widowni). Za chwilę, gdy ogląda kwilący tobołek, zagląda od razu z ciekawością, by sprawdzić płeć dziecka i z nieukrywaną radością konstatuje, że to dziewczynka (czym wywołuje kolejną falę radości na widowni). W drodze powrotnej do domu postanawia zakopać szczątki Antygonusa, które pozostały po uczcie niedźwiedzia, dochodząc do bardzo prostego wniosku, że trzeba spełnić dobry uczynek, skoro los zesłał im i ładne dziecko, i masę kosztowności razem z nim. Klown jest naiwny (czemu da wielokrotnie wyraz w drugiej części przedstawienia), prostoduszny, ale przede wszystkim jest dobrym człowiekiem.

W drugiej części spektaklu, której akcja dzieje się po upływie szesnastu lat, Klown pojawia się na scenie już na samym początku. Ubrany jest dość elegancko - czerwone spodnie, biała koszula, żakiet w kolorze bordo i świętojański wieniec na głowie. Wybierając się po zakupy, wyśpiewuje całą listę sprawunków. Bergman zmienił tu tekst Szekspira, poza tym wprowadził nawiązania do popularnych w czasach jego młodości szlagierów muzyki rozrywkowej:

Låt mig se: vad skulle jak köpa till midsommarfesten? Tre pund socker, fem pund korinter, risgryn - vad i all världen ska min syster med risgryn till? Farsan har utnämt henne till värdinna vid festen, och hon tänker tydligen slå på stort! Hon ska ha saffran att färga pajerna, (Här följer en minneslista byggd på olika melodier), mor lilla mor ... morötter! Peppar kom hem för vi längrat efter dig..., vad tar ni för löken där i fönstret? Voff voff! Yes we have no ingefära, we no have ingefära today - men det får jag nog på köpet! Come on let's persilja, like we did last summer... fyra pond sviskon och lika mycket russin. Purjolök!

\footnotetext{
2 Tekst dopisany do dramatu przez Bergmana w moim tłumaczeniu, na podstawie egzemplarza suflerskiego z Archiwum Dramaten: „Zobaczmy, co to mam kupić na dzisiejsze przyjęcie z okazji Midsommar? Trzy funty cukru, pięć funtów koryntek, ryż - po co u licha potrzebny mojej siostrze ryż? Tatuś wyznaczył ją jako gospodynię przyjęcia i najwyraźniej uważa, że można zaszaleć. Chce szafran do zażółcenia pajów [kontynuuje listę zbudowaną na różnych melodiach - przyp. M.S.-Ch.]... mamusiu ... marchewki! ... pieprzu przyjdź do domu, bo tęsknimy za tobą... cóż to za cebula tam w oknie hau hau! [tu nasuwa się skojarzenie z melodią How much is that Hound dog in the window - jest to piosenka Boba Merilla, wylansowana w 1953 r. przez duet Homer and Jethro - przyp. M. S-Ch.] Yes we have no imbir, we no have imbir today [pierwowzorem mogła być piosenka Yes we have no bananas, we have no bananas today, napisana przez Franka Silvera i Irvinga Cohna w 1923 r. w wydaniu Eddiego Vantora; była ona jednym z najbardziej znanych szlagierów lat 20. w USA - przyp. M.S-Ch.] - ale jeszcze go pewnie kupię. Come on let's pietruszka like we did last summer [nawiązanie do przeboju Let's twist again - jeden z pierwszych wielkich przebojów rock’n' rolla, wylansowany przez czarnoskórego piosenka-
} 
Ten kabaretowy numer świetnie rozbawiał publiczność. Przy okazji stanowi dowód na to, że Bergman zarówno miał poczucie humoru, jak i doskonale orientował się w muzyce rozrywkowej, o co zapewne niewielu widzów by go podejrzewało.

Przez lata naiwność Klowna nie znikła i młodzieniec daje się od razu wystrychnąć na dudka przez Autolikusa. Ten szaławiła jest również odmianą błazna - ale zarazem przeciwieństwem Klowna. Jest sprytny, kuty na cztery nogi, chciwy i egoistyczny. Przy każdorazowym spotkaniu Klowna będzie chciał go wykorzystać (co synowi pasterza nadaje rys Augusta - wprawdzie nie dostaje tortem w twarz i nie jest to slapstickowa komedia, ale to on będzie zawsze poszkodowany). Zestawienie tych dwóch postaci obfituje w humor językowy i sytuacyjny. Szczególnie gdy Autolikus pokazuje się po raz ostatni, w przebraniu franciszkańskim, i zostaje zdemaskowany przez Klowna mającego silne poczucie sprawiedliwości i wierzącego $\mathrm{w}$ zwycięstwo dobra nad złem.

Pisząc o roli błazna i klowna, nie można zapomnieć o inscenizacji, w której odegrał istotną rolę. Mam na myśli Mizantropa z 1995 roku (Bergman 1995). Spektakl rozpoczyna się przedgrą, o której już wspominałam - żywym obrazem. Celimena bawi się w ciuciubabkę. Jednak osobą ożywiającą postacie nie jest żaden magik, lecz Pierrot skopiowany z obrazów Jeana Antoina Watteau. To on podnosi kurtynę, która tym razem nie jest tą tradycyjną, błękitną, lecz znajduje się na niej inny obraz Watteau, ukazujący dwie damy i młodzieńca zasłuchanych w opowiadanie Pierrota. Po podniesieniu kurtyny podchodzi on powoli do każdej z postaci, dotyka jej delikatnie i w ten sposób ją budzi. To on jest jednocześnie i marionetką, i władcą marionetek.

Być może dlatego klown/błazen/pierrot są ulubionymi postaciami Bergmana. On sam, podobnie jak jego filmowe alter ego, mały Alexander (Bergman 1982), w teatrze staje się władcą marionetek. Napomyka o tym delikatnie Maaret Koskinen, wskazując na to, że często przedstawia się sposób, w jaki Bergman reżyseruje aktorów, poprzez odwołania do mitów o reżyserze-demonie czy manipulatorze, który wprawia kukiełki w ruch prowadzący je ku bardziej oświeconym celom (Koskinen 2001: 118).

Człowiek jako kukiełka idealnie pasuje do wizji świata reżysera. Marionetka nie wie, jakie są plany pociągającego za sznurki, może jedynie buntować się przeciwko enigmatycznym zamysłom lalkarza, lecz jej bunt obraca się w niwecz. Może też zadawać sobie pytanie - kto pociąga za sznurki? I co, jeśli nikogo tam nie ma? Wolność człowieka jest ograniczona, lecz w filmach Bergmana nigdy nie wiedziano, przez kogo - czy jest to Bóg, który jest obojętny wobec ludzkich próśb i błagań, czy jest to być może jego natura, w której skłonność do czynienia zła jest silniejsza od tej do czynienia dobra? Kto reżyseruje spektakl w teatrze życia? Bergman czuje

rza Chubby Checkera w 1961 r. - przyp. M. S-Ch.] ... cztery funty śliwek suszonych i tyle samo rodzynek. Por!" (Archiwum Dramaten 1994: 5). 
się świetnie jako władca swych marionetek, to on niepodzielnie włada w swym teatrze, oddając mu oczywiście czasami hołd i szacunek. W ten oto sposób reżyser wpisuje się w archetypiczny wzorzec Wielkiego Kuglarza, który wymienia w swojej pracy Sznajderman:

Figurę tę przypomina na przykład stale powracające w europejskiej kulturze wyobrażenie Najwyższego Boga jako Komedianta i Kuglarza, Wielkiego Błazna: czy będzie to igrający swym stworzeniem „Bóg żywy” Starego Testamentu, czy śmiejący się Bóg z midraszy, czy wreszcie obojętna na losy świata, który stworzyła dla żartu i zabawy, demiurgiczna Istota Najwyższa poetów - wyobrażenie, którego dalekim echem są także popularne w literaturze i filmie tricksterskie postaci sprytnych szelm, współczesnych sowizdrzałów, dobroczynnych i złośliwych zarazem, realizujących pierwsze wcielenie arlekina, błazna przed rozszczepieniem się osobowości na dwie przeciwstawne, biegunowo różne postaci (Sznajderman 2000: 45).

Bergman jako Wielki Kuglarz, Władca Marionetek, Wielki Błazen. Pan życia i śmierci swoich łątek. Zakochany w świecie iluzji teatru, gdzie nic nie dzieje się naprawdę. Chłopiec pochylony w skupieniu nad małym teatrzykiem lalkowym, w którym realizuje swoje kolejne przedstawienie „nie tylko ku rozrywce”. Świadomy swej wszechwładzy. Wyróżniający aktorów, kuglarzy i błaznów. Ale... w jednym $\mathrm{z}$ ostatnich scenariuszy filmowych, który należy do ciągu rozliczeniowego artysty ze sztuką - Puszy się i miota (Bergman 1997) - główny bohater, wynalazca „mówionego kinematografu”, niespełniony artysta, zamknięty w szpitalu psychiatrycznym, spotyka tam Śmierć w przebraniu Klowna, która jest kobietą. Jest wyniosła, majestatyczna, tajemnicza, a nade wszystko upiorna. Lęk przed śmiercią, który Bergman próbował od lat okiełznać, znów się pojawia. Lęk, który próbował oswoić, pracując w teatrze. Zarówno Błazen (Głupiec), jak i Śmierć należą do tej samej talii kart, którą rozdaje reżyser jako Wielki Mag. To on decyduje o ułożeniu kart, o konfiguracji postaci. Śmierć zostaje wprzęgnięta w mechanizm świata, który jest teatrem. A skoro jest to teatr, to rządzi nim reżyser, który w tym świecie, chociażby iluzorycznie ma władzę nad śmiercią. Jak sam reżyser przyznaje w swojej autobiografii:

Chodzi o to, żeby się jakoś urządzić, skrócić linie frontów, bitwa jest w każdym razie przegrana, czego innego nie można się było przecież spodziewać, mimo że żyłem w rześkim urojeniu, że Bergman pozostanie wiecznie nienaruszony: Czy istnieją szczególne reguły dla kuglarzy? - pyta aktor Skat w Siódmej pieczęci i czepia się mocno korony Drzewa Życia. Nie ma żadnych szczególnych reguł dla aktorów, mówi Śmierć i przykłada piłę do pnia (Bergman 1991: 46).

Dopiero przy głębszym poznaniu twórczości reżysera takie przypadki przestają zaskakiwać, a podkreślają jedynie obraz wszechstronnego erudyty, twórcy nie tyl- 
ko obrazów teatralnych czy filmowych, ale też myśliciela - patrzącego na świat nie tylko $z$ goryczą, ale i potrafiącego dostrzec $\mathrm{w}$ nim pokłady komizmu. Nie na darmo to właśnie klown stał się ulubioną postacią Bergmana, jego swoistym alter ego. Błazen - artysta, którego zawodem jest rozbawianie publiczności, nawet gdy jego dusza cierpi. Pod maską komedii reżyserowanych przez Bergmana znajduje się zawsze głębsza (i czasami cierpka) prawda o życiu. $Z$ drugiej strony w tragediach możemy znaleźć momenty śmiechu przez łzy i zdystansowania się wobec tego „złego” świata. Stoicki trefniś dobrze wie, że nie ma nic stałego ani pewnego, że przedstawienie kiedyś się kończy, by następnego dnia znów można było wejść na scenę i rozbawiać publiczność.

\section{Bibliografia}

Archiwum Dramaten. (1986). Niepublikowana pieśń dopisana przez Ingmara Bergmana do egzemplarza suflerskiego Hamleta Williama Szekspira.

Archiwum Dramaten. (1994). Niepublikowany tekst dopisany przez Ingmara Bergmana do egzemplarza suflerskiego Zimowej opowieści Williama Szekspira.

Bergman, I. (1953). Vi är cirkus!. Filmjournalen 4.

Bergman, I. (1991). Laterna Magica. Tłum. Z. Łanowski. Warszawa: Czytelnik.

Bergom-Larsson, M. (1993). Od klowna do pasożyta: artysta i społeczeństwo. W: J. Balbierz i B. Zmudziński (red.). Ingmar Bergman. Kraków: Uniwersytet Jagielloński. ACK „Rotunda”. Dudzik, W. (2005). Karnawały w kulturze. Warszawa: Sic!.

Fabiszak, J., M. Gibińska i M. Kapera. (2003). Szekspir: leksykon. Kraków: Znak.

Ibsen, H. (1967). Peer Gynt. Tłum. Z. Krawczykowski. Wrocław: Zakład Narodowy im. Ossolińskich.

Koskinen, M. (2001). Allting föreställer, ingenting är. Stockholm: Nya Doxa.

Shakespeare, W. (1986). Hamlet. Tłum. B.G. Hallqvist. Stockholm: Dramatens arkiv.

Shakespeare, W. (1991). Król Lear. Tłum. S. Barańczak. Poznań: W Drodze.

Shakespeare, W. (1994). Vintersagan. Tłum. B.G. Hallqvist. Stockholm: Dramatens arkiv.

Słowiński, M. (1993). Błazen: dzieje postaci i motywu. Poznań: Prolog.

Szczepański, T. (1999). Zwierciadło Bergmana. Gdańsk: Słowo/obraz terytoria.

Sznajderman, M. (2000). Błazen: maski i metafory. Gdańsk: Słowo/obraz terytoria.

Wanselius, B. (1998). Fotografia na I stronie okładki. Dramat 1.

Filmy

Fanny i Aleksander (Fanny och Alexander). (1982). [film fabularny]. Reżyseria: I. Bergman. Szwecja.

Jajo węża (The Serpent's Egg). (1976). [film fabularny]. Reżyseria: I. Bergman. Niemcy.

Puszy się i miota (Larmar och gör sig till). (1997). [film fabularny]. Reżyseria: I. Bergman. Szwecja. Rytuał (Riten). (1967). [film fabularny]. Reżyseria: I. Bergman. Szwecja.

Siódma pieczęć (Det sjunde inseglet). (1957). [film fabularny]. Reżyseria: I. Bergman. Szwecja.

Twarz (Ansiktet). (1958a). [film fabularny]. Reżyseria: I. Bergman. Szwecja.

Wieczór kuglarzy (Gycklarnas afton). (1953). [film fabularny]. Reżyseria: I. Bergman. Szwecja. 
Sztuki teatralne

Dom lalki (Ett dockhem). (1989). [spektakl teatralny]. Reżyseria: I. Bergman. Królewski Teatr Dramatyczny w Sztokholmie.

Don Juan (Don Juan). (1965). [spektakl teatralny]. Reżyseria: I. Bergman. Teatr Miejski w Malmö. Hamlet (Hamlet). (1986). [spektakl teatralny]. Reżyseria: I. Bergman. Królewski Teatr Dramatyczny w Sztokholmie.

Iwona, księżniczka burgunda (Yvonne, prinsessa av Burgund). (1996). [spektakl teatralny]. Reżyseria: I. Bergman. Królewski Teatr Dramatyczny w Sztokholmie.

Król Lear (Kung Lear). (1991b). [spektakl teatralny]. Reżyseria: I. Bergman. Królewski Teatr Dramatyczny w Sztokholmie.

Mizantrop (Misantropen). (1995). [spektakl teatralny]. Reżyseria: I. Bergman. Królewski Teatr Dramatyczny w Sztokholmie.

Peer Gynt (Peer Gynt). (1991a). [spektakl teatralny]. Reżyseria: I. Bergman. Królewski Teatr Dramatyczny w Sztokholmie.

Prafaust (Ur-Faust). (1958b). [spektakl teatralny]. Reżyseria: I. Bergman. Teatr Miejski w Malmö. Wieczór Trzech Króli (Trettondagsafton). (1975). [spektakl teatralny]. Reżyseria: I. Bergman. Królewski Teatr Dramatyczny w Sztokholmie.

Zimowa opowieść (Vintersagan). (1994). [spektakl teatralny]. Reżyseria: I. Bergman. Królewski Teatr Dramatyczny w Sztokholmie. 